\title{
Analisis Perancangan Bio Briket Biji Salak Menggunakan Bisnis Model Kanvas
}

\author{
Andri Saleh ${ }^{1}$ Dr. Rika, M.Sc ${ }^{2}$ \\ 1,2 Jurusan Teknik Industri, Fakultas Sains dan Teknologi, UIN Sultan Syarif Kasim Riau \\ Jl. HR. Soebrantas No. 155 Simpang Baru, Panam, Pekanbaru, 28293 \\ Email: rikataslim@gmail.com
}

\begin{abstract}
ABSTRAK
Indonesia merupakan negara agraris yang artinya sektor pertanian memiliki peranan yang sangat penting. Sektor pertanian juga meliputi perkebunan yang memberikan sumbangsih yang cukup signifikan untuk perekonomian negara. Diantara hasil perkebunan itu berupa sayur mayur dan buah buahan. Untuk produksi buah-buahan khususnya buah salak di Indonesia menempati urutan kelima dengan produksi sebesar 1.118.953 ton atau sekitar 5,65\% terhadap total produksi buah nasional. Padangsidimpuan merupakan salah satu kota di Sumatera Utara yang sebagian besar penduduknya bekerja sebagai petani salak dansalak merupakan komoditi pertanian yang banyak dijumpai di kota Padangsidimpuan adalah salak. Luas lahan tanaman salak di Padangsidimpuan berkisar 460 Ha dengan jumlah produksi 426.758 ton/tahun. Salah satu energi alternatif yang terus dikembangkan adalah briket. Briket merupakan bahan bakar yang berwujud padat yang terbuat dari sisa limbah biomassa. Salah satu limbah yang cukup banyakselain kulit adalah biji salak yang menjadi perhatian untuk di daur ulang sebagai energi alternatif. Briket dari biji salak merupakan ide yang cukup tepat untuk dikembangkan dalam perancangan produk bernilai ekonomis karena memiliki nilai kalor yang tinggi berdasarkan penelitian awal yang sudah dilakukan yaitu 7,058 kKal/gram. Nilai ini memenuhi nilai Standar Nasiona Indonesia dan juga Nilai Standar Internasional. Perancangan Biobriket dengan metode Design for Manufacturing dan bisnis model kanvas diawali dengan menghitung Harga Pokok Produksi (HPP), setiap memproduksi $1 \mathrm{~kg}$ briket membutuhkan HPP sebesar Rp 5,90,- dengan asumsi harga jual 50\%, maka harga jual briket tersebut sebesar Rp 8.85,-/kg. Dari hasil Analisa Business Model Canvas yang dilakukan pada pembuatan briket biji salak Model Bisnis yang dihasilkan dari pengembangan pasar produk briket biji salak dan ampas tebu disesuaikan dari kebutuhan masyarkat khususnya kalangan ibu rumah tangga dan pedagang kecil. Segi pelayanan juga bisa dimaksimalkan untuk menyesuaikan permintaan konsumen. Permasalahan channel yang dialami dalam peningkatan penjualan briket biji salak dapat ditanggulangi karna adanya analisa potensi market place yang akan menjadi target pasar untuk mendukung realisasi dan memaksimalkan potensi bisnis briket.
\end{abstract}

Kata Kunci : Briket Biji Salak, Nilai Ekonomis, Business Model Canvas.

\section{Pendahuluan}

Indonesia merupakan negara agraris yang artinya sektor pertanian memiliki peranan yang sangat penting. Sektor pertanian juga meliputi perkebunan yang juga meningkatkan perekonomian negara. Hasil perkebunan itu berupa sayur mayur dan buah buahan. Produksi buah salak di indonesia menempati urutan kelima dengan produksi sebesar 1.118.953 ton atau sekitar 5,65 \% terhadap total produksi buah nasional. Penghasil terbesar di luar jawa adalah
Sumatera Utara dengan Produksi sebesar 354,087 ton atau sekitar 31,64\% dari total produksi salak nasional (Kementrian Pertanian Direktorat Jendral Hortikultura, 2015).

Menurut data Dinas Pertanian Tanaman Pangan dan Holtikultura Padangsidimpuan 2011 bahwa kabupaten Tapanuli Selatan adalah salah satu daerah penghasil salak terbesar di Sumatera Utara. Berdasarkan data yang diperoleh bahwa terdapat lima kecamatan penghasil salak di kabupaten Tapanuli Selatan, seperti pada tabel berikut ini: 
Tabel 1. Daerah penghasil salak di kabupaten tapanuli selatan

\begin{tabular}{|c|c|c|c|}
\hline No. & Kecamatan & Luas Area (Ha) & Jih. Produksi (Ton) \\
\hline 1 & Angkola Barat & 17.666 & 397.485 \\
\hline 2 & Angkola Selatan & 466 & 10.485 \\
\hline 3 & Angkola Timur & 436 & 9.810 \\
\hline 4 & Marancar & 363 & 8.168 \\
\hline 5 & Sayur Matinggi & 36 & 810 \\
\hline & Jumlah & $\mathbf{1 8 . 9 6 7}$ & $\mathbf{4 2 6 . 7 5 8}$ \\
\hline
\end{tabular}

(Sumber: Dinas Pertanian, Tanaman Pangan dan Holtikultura, 2011)

Namun luas lahan dan potensi yang dimiliki petani salak ini tidak termanfaatkan dengan baik. Kurangnya pengetahuan teknologi para petani adalah salah satu penyebab utama sehingga petani kurang mendapatkan keuntungan dari potensi yang ada. Masyarakat kota Padangsidimpuan umumnya hanya menjual buah salak kepada pengepul, namun beberapa pengusaha memaksimalkan potensi buah salak dengan mengolah hasil perkebunan salak menjadi makanan seperti dodol salak, manisan salak, kurma salak dan lain-lain. Namun begitu terdapat beberapa permasalahan lingkungan yang disebabkan oleh limbah. Adapun permasalahan ini ditinjau dari limbah rumah tangga maupun Usaha Kecil Menengah yang berasal dari olahan buah salak. Limbah merupakan buangan yang dihasilkan dari suatu proses produksi baik industri maupun domestik (rumah tangga), dimana kehadirannya pada suatu saat dan tempat tertentu tidak dikehendaki lingkungan karena tidak memiliki nilai ekonomis (Badan Pusat Statistik Padangsidimpuan, 2016).

Salah satu usaha untuk menanggulangi masalah lingkungan dan diharapkan juga dapat meningkatkan perekonomian yaitu dengan memanfaatkan limbah biji salak untuk sumber energi yaitu mengolahnya menjadi biobriket. Biobriket merupakan batangan arang yang terbuat dari arang limbah organik yang telah dicetak sedemikian rupa yang memiliki nilai kalor yang tinggi. Biobriket banyak dimanfaatkan sebagai bahan bakar boiler untuk menghasilkan uap, selain itu panas dari briket dapat dikonversikan menjadi listrik dan disektor kecil skala rumah tangga briket digunakan sebagai bahan bakar pengganti minyak tanah dan kayu bakar. Biobriket merupakan salah satu alternatif pemanfaatan limbah guna meningkatkan nilai tambah limbah hasil pertanian dan sebagai bahan pengganti batubara sebagai bahan bakar boiler. Proses "briquetting" adalah perubahan bentuk secara fisik pada bahan baku yang sebagian besar berasal dari limbah pertanian menjadi briket sebagai bahan bakar dengan proses pemadatan (Gover, 1996).

Pada tahun 2013 Melina Getisari dkk dari Universitas Muhammadiyah Pontianak melakukan pelatihan briket berbahan baku biji salak, pada pelatihan ini pembuatan briket tidak dilakukan pengujian nilai kalor. Tahun 2016 Hardiansyah dari Universitas Andalas melakukan perancangan briket yang dikombinsikan dengan tempurung kelapa yang menghasilkan nilai kalor 5.304,623. Kemudian tahun 2017 Andri Saleh dari Uin Suska Riau melalui Penelitian yang digagas LPPM membuat briket berbahan baku biji salak yang dikombinasikan dengan perekat alami yaitu ampas tebu yang menghasilkan nilai kalor sebesar 7.038,001. Hal tersebut melatar belakangi penelitian ini untuk memanfaatkan potensi limbah biji salak yang ada di daerah padangsidimpuan. Briket biji salak mengandung nilai kalor yang tinggi yang mendukung untuk dijadikan sebagai alternatif energi pengganti kayu bakar, minyak tanah ataupun gas.

Berdasarkan penelitian terdahulu, maka disimpulkan bahan baku biji salak sangat potensial untuk dikembangkan dalam skala UKM. Untuk itu pada penelitian ini Design for Manufacturing diyakini metode yang dapat digunakan sebagai acuan untuk pengembangan briket skala kecil dan menengah. DFM merupakan suatu proses perancangan produk yang bertujuan untuk memudahkan proses perakitan. Design for Manufacturing berkaitan desain produk dalam semua aspek dari proses manufaktur dalam rangka untuk mengoptimalkan kemampuan manufaktur dari desain awal (Ulrich, 2001).

Untuk memperjelas arah pengembangan usaha briket biji salak maka diperlukan strategi bisnis yang baik untuk mampu meningkatkan keunggulan kompetitif dari produk yang diciptakan. Model Business menjadi sangat penting di dalam perusahaan, karena model bisnis merupakan suatu capture bagaimana bisnis tersebut berlangsung dan merupakan arsitektur atau bangunan dari sebuah bisnis unit yang 
digunakan untuk melihat gambaran dari bisnis tersebut. Salah satu alat yang digunakan untuk menganalisis model bisnis adalah Business Model Canvas yang ditemukan oleh Osterwalder dan Pigneur di tahun 2010. Business Model Canvas lebih mudah dipahami dan diaplikasikan serta merupakan alat analisa yang paling popular dan terbaru dan lebih cocok menganalisa industri karena memilki komponen yang lebih lengkap dibandingkan alat analisa yang lainnya (Kristiani, 2015).

Tujuan penelitian yang dilakukan dalam penelitin ini adalah Memperhitungkan Harga pokok produksi Briket biji salak, menganalisa Design for Manufactur untuk pengolahan limbah biji salak menjadi briket dan mengetahui potensi bisnis briket biji salak dengan Bisnis Model Canvas.

Metodologi Penelitian

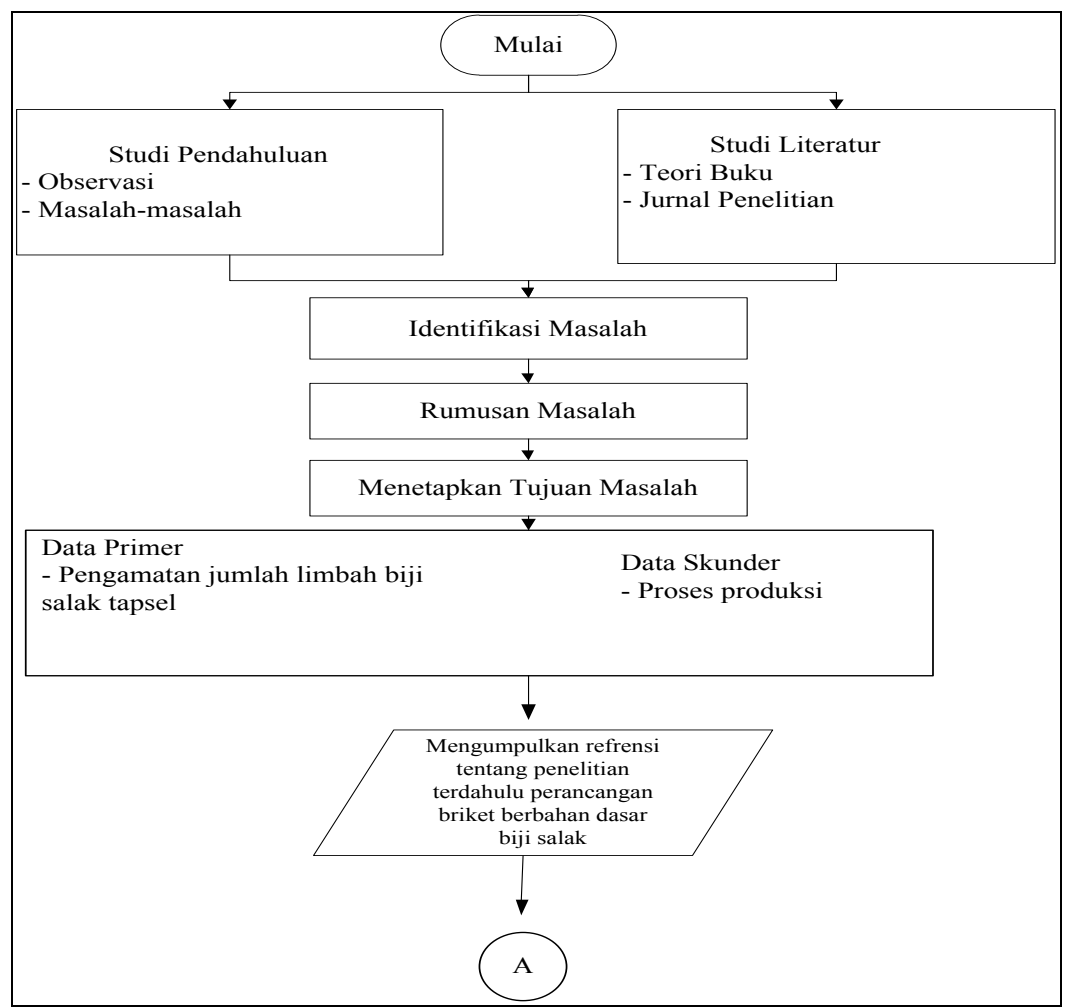

Gambar 1. Flowchart 


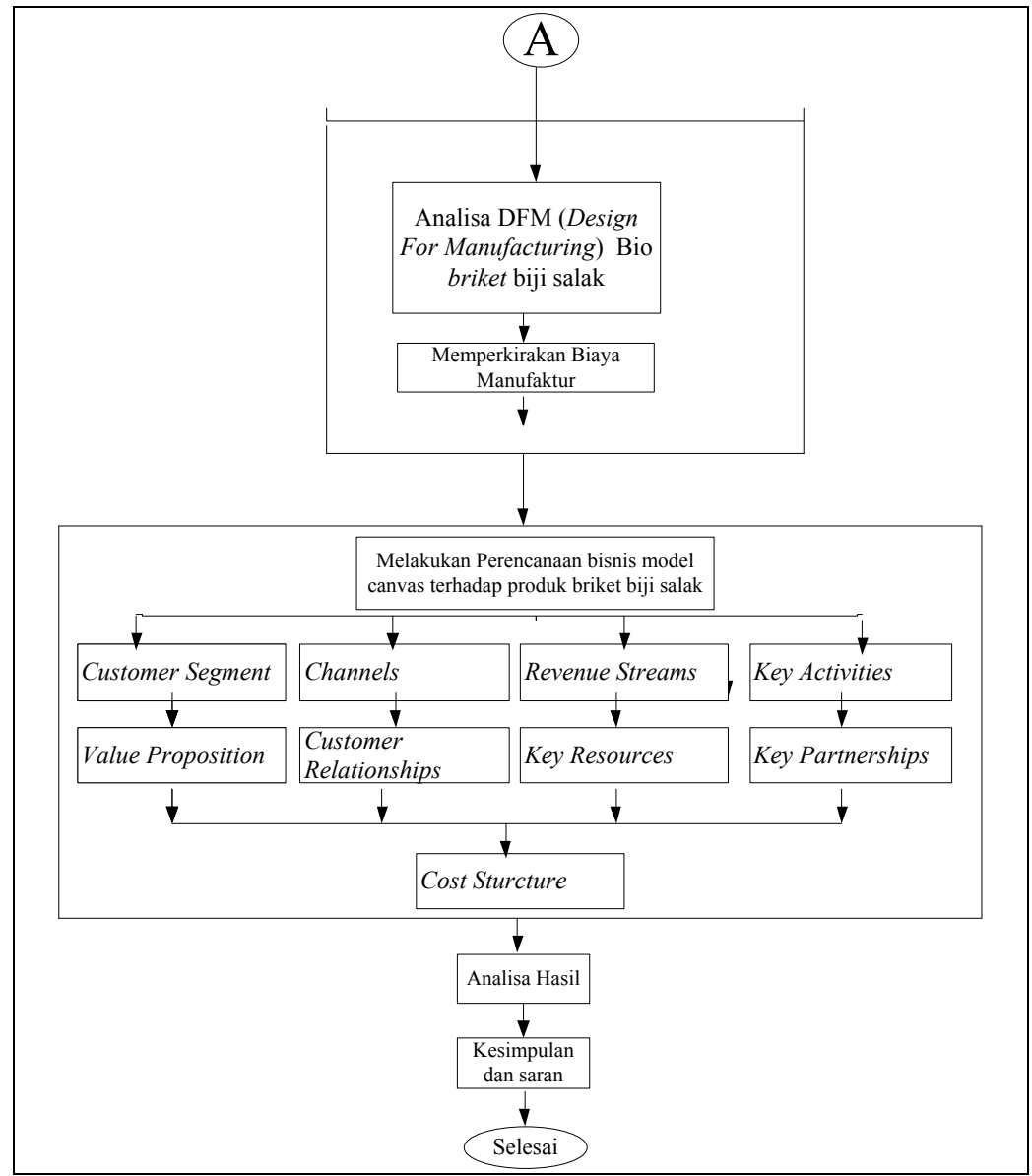

Gambar 2. Flowchart Lanjutan

\section{Hasil dan Pembahasan}

Proses pengadonan briket dilakukan dengan 3 variasi yaitu $95 \%$ biji salak $+5 \%$ ampas tebu, $90 \%$ biji salak $+10 \%$ ampas tebu, $85 \%$ biji salak $+15 \%$ ampas tebu.

Tabel 2. Jumlah adoanan

\begin{tabular}{|c|c|}
\hline Biji Salak & Ampas Tebu \\
\hline $95 \%$ & $5 \%$ \\
\hline $90 \%$ & $10 \%$ \\
\hline $85 \%$ & $15 \%$ \\
\hline
\end{tabular}

Tujuan dilakukannya 3 variasi dalam pengadonan untuk mendapatkan komposisi terbaik dalam proses pembuatan briket. Setelah bahan baku diadon kemudian dilakukan proses pencetakan briket, proses pencetakan menggunakan alat Hidrolik press dengan tekanan Tabel 3 Nilai kalor briket biji salak dan ampas tebu

\begin{tabular}{|c|c|}
\hline Sampel & $\begin{array}{c}\text { Nilai kalor } \\
\text { (kKal/kg) }\end{array}$ \\
\hline $\mathrm{BSAT}_{1}$ & $7.058,1$ \\
\hline $\mathrm{BSAT}_{2}$ & $6.906,4$ \\
\hline
\end{tabular}

2 ton $\left(2500 \mathrm{KN} / \mathrm{m}^{2}\right)$. Setelah dicetak briket dikeringkan menggunakan oven dengan suhu 100 ${ }^{\circ} \mathrm{C}$ selama 90 menit, dan dijemur dibawah sinar matahari selama 1 hari. (Rizky, 2015)

Tahapan terakhir dalam pembuatan briket adalah dengan melakukan pengujian nilai kalor. Nilai kalor sangat menentukan kualitas briket. Semakin tinggi kalor bakar briket, semakin baik pula kualitas briketnya. Untuk mengetahui nilai kalor suatu bahan bakar, pengujian yang umum dilakukan adalah pengujian kalor dengan menggunakan bomb calorimeter. Dari hasil pengujian kadar kalor yang dilakukan dengan menggunakan alat tersebut di laboraturium Pengujian Bahan di Lab. Teknik Mesin, Fakultas Teknik Universitas Riau diperoleh data sebagai berikut:

\begin{tabular}{|l|l|}
\hline $\mathrm{BSAT}_{3}$ & $7.035,4$ \\
\hline
\end{tabular}

Sebagai perbandingan nilai kalor briket hasil penelitian ini ditabelkan dengan nilai kalor standar briket oleh beberapa negara penghasil briket, yaitu seperti yang tertera pada Tabel 4.4 
Tabel 4.4 Perbandingan Nilai Kalor Briket Biji

Salak dan Ampas Tebu dengan Standar Negara.

Tabel 4. Nilai kalor

\begin{tabular}{|c|c|c|c|c|c|c|}
\hline \multirow{2}{*}{ No } & \multirow{2}{*}{ Sampel } & \multicolumn{5}{|c|}{ Nilai Kalor (Kkal/kg) } \\
\cline { 3 - 6 } & & Penelitian & Indonesia* & Inggris* & Jepang* & USA* \\
\hline 1. & $\mathrm{BSAT}_{1}$ & $7.058,1$ & & & \\
\hline 2. & $\mathrm{BSAT}_{2}$ & $6.906,4$ & $<5000$ & 7300 & $6000-7000$ & 6200 \\
\hline 3. & $\mathrm{BSAT}_{3}$ & $7.035,4$ & & & \\
\hline
\end{tabular}

Dari perbandingan yang dilakukan dapat dilihat bahwa semua sampel mencakup standar yang telah ditetapkan Indonesia, USA dan Jepang, itu artinya briket pada penelitian yang dilakukan dengan bahan baku biji salak dan ampas tebu memiliki kualitas nilai kalor yang cukup tinggi, dan sampel yang paling itu adalah sampel $\mathrm{BSAT}_{1}$ yaitu sebesar $7.058,1 \mathrm{kKal} / \mathrm{gr}$.

Analisis biaya dilakukan untuk menghitung biaya yang dibutuhkan dalam proses produksi briket biji salak yang dihasilnya kemudian dijadikan acuan untuk menentukan harga jual produk.

Tabel 5. Biaya bahan langsung

\begin{tabular}{|c|c|c|}
\hline Keterangan & Jumlah & Satuan \\
\hline Jumlah hari kerja & 25 & hari/Bulan \\
\hline Kapasitas Produksi & 100 & $\mathrm{~kg} / \mathrm{Bulan}$ \\
\hline Kebutuhan Ampas Tebu & 5 & $\mathrm{~kg} / \mathrm{Bulan}$ \\
\hline Harga Ampas Tebu & Gratis & $\mathrm{Rp} / \mathrm{kg}$ \\
\hline Kebutuhan Biji Salak & 2000 & $\mathrm{~kg} / \mathrm{Bulan}$ \\
\hline Harga Biji Salak & 200 & $\mathrm{Rp} / \mathrm{kg}$ \\
\hline Total & $\mathbf{1 0 . 0 0 0 . 0 0 0}$ & Perbulan \\
\hline
\end{tabular}

Tabel 6. Biaya Tenaga Kerja Langsung

\begin{tabular}{|c|c|c|}
\hline Keterangan & Jumlah & Satuan \\
\hline Hari kerja perbulan & 25 & hari/bulan \\
\hline Hari kerja pertahun & 300 & hari/tahun \\
\hline Jumlah pekerja & 4 & Orang \\
\hline Upah pekerja & Rp. 50.000 & perorang/hari \\
\hline Total upah pekerja & Rp. $\mathbf{6 0 . 0 0 0 . 0 0 0}$ & Pertahun \\
\hline
\end{tabular}

Tabel 7. Biaya tidak langsung

\begin{tabular}{|c|c|c|}
\hline Keterangan & Biaya Perbulan & Biaya Pertahun \\
\hline Sewa gedung pabrik & - & Rp 5.000 .000 \\
\hline Pemeliharaan Mesin & Rp 500.000 & Rp 6.000 .000 \\
\hline Listrik & Rp 800.000 & Rp 1.600 .000 \\
\hline Bahan Bakar & Rp 1.000 .000 & Rp 12.000 .000 \\
\hline
\end{tabular}

Harga pokok produksi diperoleh dengan menjumlahkan seluruh biaya yang dikeluarkan untuk memproduksi briket biji salak. Kemudian setelah harga pokok produksi diperoleh, digunakan asumsi margin 50\%.

Kapasitas produksi perbulan $=1200 \mathrm{~kg}$

Kapasitas produksi pertahun $=14.400$ $\mathrm{kg} /$ tahun
HPP Perkilogram $=\frac{\text { Rp85.000.000/tahun }}{14.400 \mathrm{~kg} / \text { tahun }}$

HPP Perkilogram $=$ Rp 5.90/kg

Harga Jual Briket Perkilogram dengan Margin $50 \%$

$=\operatorname{Rp} 5.90+(5.90 \times 50 \%)$

$=\operatorname{Rp} 8.85=$ Rp. $1000 / \mathrm{Kg}$ 
Pada proses produksi biobriket membutuhkan mesin yang digunakan dalam pengeringan bahan baku, pra-karbonisasai,
Pencacahan, Penghalusan, dan pengujian nilai kalor yang dihasilkan.Kebutuhan Mesin pada pembuatan briket dapat diuraikan sebagai berikut:

Tabel 8. Kebutuhan mesin

\begin{tabular}{|c|l|c|c|c|c|c|c|c|}
\hline No & Jenis Mesin & DT (Jam) & $\mathbf{S}_{\text {T }}(\mathbf{J a m})$ & $\mathbf{D}(\mathbf{J a m})$ & $\mathbf{E}(\%)$ & T (Jam) & P (Unit) & N \\
\hline 1 & Oven Listrik $110^{\circ}$ & 0 & 0,5 & 12 & 0,96 & 12 & 50 & 0,86 \\
\hline 2 & Grinder & 0 & 0,5 & 2 & 0,75 & 12 & 50 & 0,88 \\
\hline 3 & Ball milling & 0 & 2 & 8 & 0,87 & 10 & 50 & 0,91 \\
\hline 4 & Hot Press & 0 & 0,5 & 8 & 0,94 & 2 & 50 & 0,19 \\
\hline 5 & Bombcalori meter & 0 & 2 & 8 & 0,87 & 12 & 50 & 0.86 \\
\hline
\end{tabular}

Berdasarkan identifikasi mengenai penerapan Analisa business model canvas pada briket biji salak sebagai berikut:

1. Elemen customer segment, yang menjadi fokus utama dari UKM salacca sebagai pengembang briket biji salak yaitu para ibu rumah tangga, pedagang kecil yang memerlukan bahan bakar murah dan berkualitas.

2. Elemen value propositions, hal yang diutamakan yaitu pelayanan terbaik kepada konsumen dari segi jaminan pengembalian produk, ketepatan waktu pada saat proses produksi dan disain sesuai permintaan konsumen.

3. Elemen channel pada pengembangan briket biji salak melalui penjualan langsung dan bekerjasama dengan market place daerah yang sudah mulai berkembang dikawasan padangsidimpuan yaitu poken.com.

4. Elemen customer relationships, dalam menjaga hubungan yang baik dengan pelanggan.

\section{Kesimpulan dan Saran}

Dalam pengembangan briket biji salak dengan Design for Manufacturing dibutuhkan biaya untuk memproduksi $1 \mathrm{~kg}$ briket dengan menggunakan perhitungan harga pokok produksi adalah Rp 5.90,-. Dengan Margin 50\% maka harga jual briket perkilogramnya adalah Rp 8.85 . bertujuan untuk mengetahui Harga Pokok Produksi dalam pengembangan briket biji salak dan ampas tebu hal ini bertujuan untuk meminimalkan produksi tetapi tidak mengurangi kualitas produk briket yang dihasilkan

Dari hasil Analisa Business Model Canvas yang dilakukan pada pembuatan briket biji salak Model Bisnis yang dihasilkan dari pengembangan pasar produk briket biji salak dan ampas tebu disesuaikan dari kebutuhan masyarkat khususnya kalangan ibu rumah tangga dan pedagang kecil. Segi pelayanan juga bisa dimaksimalkan untuk menyesuaikan permintaan konsumen. Permasalahan channel yang dialami dalam peningkatan penjualan briket biji salak dapat ditanggulangi karna adanya analisa potensi market place yang akan menjadi target pasar untuk mendukung realisasi dan memaksimalkan potensi bisnis briket.

\section{Daftar Pustaka}

[1] Andri Saleh, Penelitian LPPM Uin Suska Riau 2017

[2] Dinas Pertanian, Tanaman Pangan dan Holtikultura

[3] P.D Grover \& S.K Mishra, Biomass Briquetting, FAOUN, Bangkok, 1996 https://padangsidimpuankota.bps.go.id

[4] Ulrich, Karl.T, \& Steven Eppinger, ProductDesign and Development International Edition, McGraw-Hill, 2001.

[5] Wheelen and Hunger . Business Model and Strategies : Text and Cases. New York:Mc.Graw-hill. 2003. 